\title{
Evaluation in Vitro of Blueberry Germplasm for Higher pH Tolerance
}

\author{
Chad E. Finn', James J. Luby', Carl J. Rosen², and Peter D. Ascher ${ }^{3}$ \\ Department of Horticultural Science and Landscape Architecture, University of Minnesota, \\ Saint Paul, MN 55108
} Additional index words. blueberry breeding, Vaccinium corymbosum, Vaccinium angustifolium, Vaccinium corymbosum/
V. angustifolium hybrid derivatives, diallel cross, genetic variance components, combining ability

\begin{abstract}
Progenies from crosses among eight highbush (Vaccinium corymbosum L.), lowbush (V. angustifolium Ait.), and $V$. corymbosum/ $V$. angustifolium hybrid-derivative parents were evaluated in vitro at low (5.0) and high (6.0) $\mathrm{pH}$ for vitality, height, and dry weight. Succinic acid and 2[ $N$ - morpholino]ethanesulfonic acid (Mes) effectively maintained pH in the medium and rhizosphere. The pH regime did not affect percent radicle emergence from seed or survival; however, percent seed germination was slightly lower at high $\mathbf{p H}$. The parental general combining ability (GCA), reciprocal and maternal, but not the specific combining ability (SCA) variance components were significant for plant vitality, height, and dry weight. The GCA variance components were six to 26 times larger than the SCA variance components for the plant growth traits. Variation due to $\mathrm{pH}$ regime was significant for vitality and dry weight but not for plant height. The progenies of parents with high percent lowbush ancestry were taller at both pH levels than those with less such ancestry. Little variation was apparent for higher $\mathrm{pH}$ tolerance as measured by dry weight; however, the GCA effects suggested that the progenies of some parents performed better than others at high pH. Vaccinium angustifolium parents differed in the extent to which tolerance to high pH was transmitted. In vitro screening in concert with a traditional breeding program should be effective in improving blueberry tolerance to higher pH.
\end{abstract}

Highbush blueberry is typically found in sites with low $\mathrm{pH}$ and moist soils that are high in organic matter (Cain, 1952; Coville, 1910; Galletta, 1975; Harmer, 1944; Korcak et al., 1982). Commercial blueberry production is limited to soils with inherently low $\mathrm{pH}$ or that have been treated with acidifying soil amendments (Ballinger, 1966; Chandler et al., 1985). The pH range for optimal blueberry $(V$. angustifolium Ait., $V$. corymbosum) growth is between 4.5 and 5.2 (Hall et al., 1964; Harmer, 1944; Johnston, 1948; Townsend, 1966, 1967, 1969). Recognition of the acidic soil requirements, coupled with the knowledge that nutrient availability and plant metabolism are affected by changing $\mathrm{pH}$ levels, provided an avenue of research for understanding poor blueberry growth at higher than optimal $\mathrm{pH}$ levels. Initial inquiries concentrated on the availability of macronutrients, such as $\mathrm{Ca}$, that were often associated with $\mathrm{pH}$ changes (Bailey, 1941; Cain, 1952; Harmer, 1944; Kramer and Schrader, 1942). Later investigations focused on micronutrient effects as these were being studied in many crop plants (Twyman, 1946, 1950). Iron received the greatest attention, because blueberries often exhibited the appearance of iron deficiency on higher pH soils (Bradley and Smittle, 1965; Cain, 1952, Cain and Honey, 1955; Holmes, 1960).

Although $\mathrm{NO}_{3}-\mathrm{N}$ alone or in combination with $\mathrm{NH}_{4}-\mathrm{N}$ is recognized as being more efficient than $\mathrm{NH}_{4}-\mathrm{N}$ alone for the nutrition of many crops, the Ericaceous plants readily use $\mathrm{NH}_{4}-\mathrm{N}$ (Ingestad, 1973; Townsend, 1966, 1967, 1969). Ammonium is the predominant inorganic form of $\mathrm{N}$ at native blueberry sites; thus, some researchers have suggested that blueberries grow

Received for publication 5 Feb. 1990. Scientific Journal series paper no. 18,287. Minnesota Agricultural Experiment Station, St. Paul. This research was supported, in part, by the U.S. Dept. of Agriculture under Specific Cooperative Agreement no. 58-32U4-7-047. The cost of publishing this paper was defrayed in part by the payment of page charges. Under postal regulations, this paper therefore must be hereby marked advertisement solely to indicate this fact.

'Research Assistant. Current address: Dept. of Horticulture, Univ. of Missouri, Columbia, MO 65211

${ }^{2}$ Associate Professor.

${ }^{3}$ Professor. poorly on higher $\mathrm{pH}$ soils due to inefficient use of $\mathrm{NO}_{3}-\mathrm{N}$, the predominant inorganic nitrogen form at high $\mathrm{pH}$ levels (Cain, 1952, Havill et al., 1974; Rorison, 1986).

Over the last several years, blueberry researchers have tried to formulate an inclusive theory on blueberry intolerance of high pH soils (Korcak, 1989). Although this research has allowed the development of cultural systems that adapt the soil medium to the plant, it has not yet led to the development of cultivars adapted to variable soils.

Brown and Draper (1980), using a greenhouse solution culture screening method, identified populations, derived from $V$. ashei Reade, V. darrowi Camp, and V. corymbosum, that varied in the ability to lower the $\mathrm{pH}$ of nutrient solutions by releasing $\mathrm{H}^{+}$ions from the roots. This process freed $\mathrm{Fe}$ that accumulated on roots, making it available for plant use. Progenies exhibiting this trait were termed Fe-efficient and were thought to be tolerant of high solution $\mathrm{pH}$. Brown and Draper suggested that breeding programs designed to improve $\mathrm{Fe}$ efficiency would yield plants adapted to a wider soil $\mathrm{pH}$ range.

Ideally, cultivars adapted to upland mineral soils would be tolerant of lower organic matter, higher $\mathrm{pH}$, and lower average moisture content than is typical of native blueberry sites (Chandler et al., 1985). Korcak et al. (1982), using broad-based germplasm derived from $V$. corymbosum, $V$. ashei, $V$. darrowi, $V$. tenellum Ait., V. atrococcum (Gray) Heller, and $V$. angustifolium, found variability among populations and individuals for tolerance to upland mineral soils. Vaccinium angustifolium appeared to be the best germplasm source for adaptation to mineral and high $\mathrm{pH}$ soils, based on the progenies of interspecific hybrids (Korcak, 1986a, 1986b; Korcak et al., 1982). Galletta (1975) also suggested that $V$. angustifolium maybe a source for adaptation to a broader range of physical and chemical soil characters.

Chandler et al. (1985) determined that the general combining ability (GCA) variance components were much greater than specific combining ability (SCA) components for upland soil adaptability, as measured by plant canopy volume, in progenies derived from $V$. corymbosum, $V$. angustifolium, $V$. ashei, V. atrocco- 
cum, V. myrtilloides Michx., V. myrsinites Lamarck, and $V$. darrowii. This result suggested that a breeding scheme designed to maximize improvement due to additive genetic variance would produce populations more adapted to upland soils.

Chandler et al. (1985) also recognized that soil variability in the field had a large effect on seedling vigor. They suggested that initial screening for upland soil adaptability be done in the greenhouse or in a place where soil conditions could be carefully controlled. Field and greenhouse screening procedures have been described to identify individuals or populations more tolerant of upland soils (Korcak, 1986a; Korcak et al., 1982) or high pH (Finn et al., 1987).

In vitro systems provide a more highly controlled environment than field or most nonfield screening environments. In vitro systems have been used in blueberry research to study propagation (Chandler and Draper, 1986; Frett and Smagula, 1983; Hall, 1976; Lyrene, 1980; Nickerson, 1978; Wolfe et al., 1983, 1986; Young and Cameron, 1985; Zimmerman and Broome, 1980) and in research of other fruit species to examine or stimulate genetic variation (Hurwitz and Agrios, 1984; Kouider et al., 1984; McPheeters and Skirvin, 1980; Navarro et al., 1985). An in vitro screening system can be closely controlled and yet be sufficiently flexible to allow nutrient or $\mathrm{pH}$ level adjustments. Blueberries are one of the few fruit crops that can be screened on a whole-plant basis in vitro, due to their small seedling size and relatively slow growth rate. An in vitro screening system might provide for rapid, efficient, and economic screening of seedling material for higher $\mathrm{pH}$ tolerance.

The objectives of this study were to: 1) study the inheritance of tolerance to higher $\mathrm{pH}$ in the seedlings of progenies derived from $V$. angustifolium, $V$. corymbosum, or $V$. angustifolium $/ V$. corymbosum ancestry; 2) examine the response of blueberry plants to different in vitro $\mathrm{pH}$ levels, when both $\mathrm{NO}_{3}-\mathrm{N}$ and $\mathrm{NH}_{4}-\mathrm{N}$ forms are available in the media and the variation in iron availability is minimized; and 3) establish an in vitro screening system to identify individual seedlings or populations that exhibit higher $\mathrm{pH}$ tolerance.

\section{Materials and Methods}

The eight parents included representatives from $V$. angustifolium, $V$. corymbosum, and $V$. corymbosum $/ V$. angustifolium derivatives and were crossed in a complete diallel with reciprocals (Table 1). Seeds from the 64 crosses were extracted from

Table 1. Identification and ancestry of Vaccinium clones used as parents in the diallel cross.

\begin{tabular}{|c|c|}
\hline Parent ${ }^{z}$ & Species ancestry \\
\hline $\mathrm{N} 70127^{y}$ & Vaccinium angustifolium \\
\hline $\mathrm{N} 70145^{\mathrm{x}}$ & $V$. angustifolium \\
\hline GR-1y & $V$. angustifolium $/ V$. corymbosum \\
\hline MN-61 & $\begin{array}{l}\text { V. corymbosum (USDA 11-93) } \times V \text {. angustifolium var. } \\
\text { nigrum }\end{array}$ \\
\hline Northblue & $V$. angustifolium $/ V$. corymbosum \\
\hline B-16 & $V$. conymbosum $(\mathrm{G} 65) \times V$. corymbosum (Ashworth) \\
\hline Spartan & V. corymbosum \\
\hline Bluejay & V. corymbosum \\
\hline
\end{tabular}

${ }^{\mathrm{z}}$ Numbers are Minnesota fruit accession numbers; MN, B, and GR prefixes indicate selections from the Minnesota program. G65 is a selection from the U.S. Dept. of Agriculture breeding program.

${ }^{y}$ Clone resulting from open-pollination of a $V$. angustifolium $/ V$. cor ymbosum derivative of unknown origin growing in the Harvard Forest (Massachusetts); selected at Grand Rapids, Minn.

${ }^{\times}$Collected from a wild stand in northern Minnesota. fresh fruit, sterilized for $5 \mathrm{~min}$ with diluted commercial bleach $(20 \%)$, rinsed with sterilized distilled water, and planted on an agar nutrient medium in glass jars $(6 \mathrm{~cm}$ diameter $\times 10 \mathrm{~cm}$ height, $30 \mathrm{ml}$ medium per jar). Twenty seeds were planted in each jar. A modified Zimmerman's medium (Zimmerman and Broome, 1980) was used of the following composition: (mM), $\mathrm{NH}_{4} \mathrm{~N} \mathrm{O}_{3}, 0.4 ;\left(\mathrm{NH}_{4}\right)_{2} \mathrm{SO}_{4}, 0.3 ; \mathrm{Ca}\left(\mathrm{NO}_{3}\right)_{2} \cdot 4 \mathrm{H}_{2} \mathrm{O}, 0.6 ; \mathrm{KNO}_{3}$, $0.4 ; \mathrm{KH}_{2} \mathrm{P} \mathrm{O}_{4}, 0.6 ; \mathrm{MgSO}_{4}-7 \mathrm{H}_{2} \mathrm{O}, 0.3 ; \mathrm{FeSO}_{4} \cdot 7 \mathrm{H}_{2} \mathrm{O}, 0.2$; $\mathrm{Na}_{2}$ EDTA, $0.2 ; \mathrm{MnSO}_{4} \cdot \mathrm{H}_{2} \mathrm{O}, 0.1 ; \mathrm{H}_{3} \mathrm{BO}_{3}, 0.1 ;(\mu \mathrm{M}), \mathrm{KI}, 5.0$; $\mathrm{Na}_{2} \mathrm{MoO}_{4} \cdot 2 \mathrm{H}_{2} \mathrm{O}, 1.0 ; \mathrm{CoCl}_{2} \cdot \mathrm{H}_{2} \mathrm{O}, 0.1 ; \mathrm{CuSO}_{4} \cdot 5 \mathrm{H}_{2} \mathrm{O}, 0.1$. Agar was added to the medium at $5.5 \mathrm{~g} \cdot \operatorname{liter}^{-1}$. The $\mathrm{pH}$ was adjusted with $\mathrm{NaOH}$ to either 5.0 or 6.0 . The lower $\mathrm{pH}$ was chosen because it falls within the $\mathrm{pH}$ range where optimal blueberry growth occurs in soils and it was above the range where agar solidification can be a problem. The higher $\mathrm{pH}$ was chosen because, in preliminary experiments at $\mathrm{pH}$ 6.0, the plants exhibited a stress response and growth differences could be observed among plants. Succinic acid $\left(0.01 \mathrm{M} ; \mathrm{pK}_{\mathrm{a}}\right.$ at $25 \mathrm{C}=$ 4.19 and 5.57) and Mes, $\left(0.02 \mathrm{M} ; \mathrm{pK}_{\mathrm{a}}\right.$ at $\left.25 \mathrm{C}=6.15\right)$ were used to maintain the initial $\mathrm{pH}$ levels over the course of the study. Jars were capped, loosely sealed with Parafilm, and placed in a germination room under fluorescent lights [photosynthetic photon flux density $(\mathrm{PPFD})=30 \mu \mathrm{mol} \cdot \mathrm{s}^{-1} \cdot \mathrm{m}^{-2}, 30 \mathrm{~cm}$ from light] that were programmed for a 14-hr light and 10-hr dark period. The chamber was maintained at $22 \mathrm{C}$ and $65 \% \mathrm{RH}$.

The $\mathrm{pH}$ of the bulk medium was measured at the end of the experiment with a Corning combination (\#476115) surface probe. Rhizosphere $\mathrm{pH}$ was measured using a microelectrode [(MEPH1), World Precision Instruments; New Haven, Conn.] by inserting the probe to within $2 \mathrm{~mm}$ of the root surface.

Plants were grown for 21 weeks. At the conclusion of the experiment, data were collected on plant survival and growth traits described in Table 2. Analyses of variance were computed for a completely randomized design. One self-pollinated population failed to produce seed; therefore, only 63 populations were analyzed. A modified Griffing's Method 3 model (Griffing, 1956) was used to analyze the set of populations without the self-pollinated crosses. The parental effects were considered fixed variables. The GCA, SCA, maternal, and reciprocal var-

Table 2. Survival and plant growth traits evaluated on a per-jar basis for Vaccinium progenies grown in vitro.

\begin{tabular}{|c|c|}
\hline Trait & Description \\
\hline \multicolumn{2}{|c|}{ Survival traits (\%) } \\
\hline Germination & $\begin{array}{l}{[1-(\text { No. of seeds that did not produce a radi- }} \\
\text { cle } / 20)] \times 100\end{array}$ \\
\hline \multicolumn{2}{|r|}{$[101200] \times 100$} \\
\hline emergence & $\begin{array}{l}\text { (No. of seeds that produced a radicle and grew } \\
\text { no further } / 20) \times 100 \text {. }\end{array}$ \\
\hline \multicolumn{2}{|r|}{ 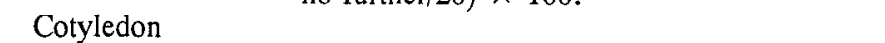 } \\
\hline emergence & $\begin{array}{l}\text { (No. of seeds that produced both a radicle and } \\
\text { cotyledon before senescing } / 20) \times 100 \text {. }\end{array}$ \\
\hline Survival & $\begin{array}{l}\text { (No. of plants that survived until the experi- } \\
\text { ment's conclusion } / 20) \times 100 \text {. }\end{array}$ \\
\hline \multicolumn{2}{|l|}{$\begin{array}{l}\text { Plant growth } \\
\text { traits }\end{array}$} \\
\hline Vitality & $\begin{array}{l}\text { Overall vitality of the progeny }(1=\text { chlorotic } \\
\text { and/or weak, } 9=\text { green, healthy, and vigor- } \\
\text { ous). }\end{array}$ \\
\hline $\mathrm{Ht}$ & $\begin{array}{l}\text { Total ht (mm) of all surviving plants per no. of } \\
\text { surviving plants. }\end{array}$ \\
\hline Dry wt & $\begin{array}{l}\text { Total dry wt (g) (roots and shoots) of all surviv- } \\
\text { ing plants per no. of surviving plants. }\end{array}$ \\
\hline
\end{tabular}


iance components, along with the GCA and maternal effects, were estimated.

\section{Results and Discussion}

Most of the seeds germinated in 2 to 3 weeks. Very few plants died after producing true leaves. Many plants had grown to the top of the jars $(\approx 10 \mathrm{~cm})$ when the experiment wasterminated. Although plant growth was adequate for the purposes of this study, a light source with a higher PPFD might enhance growth rates and, thus, shorten the screening period. The plants at pH 6.0 looked nearly as tall as those at pH 5.0, but they were more chlorotic and had smaller leaves. Some individuals and populations under both regimes appeared more vigorous and/or less chlorotic, suggesting that visual selection of superior seedlings was possible both within and between populations. These growth differences due to $\mathrm{pH}$ effects paralleled observations with in vitro growth of 'Bluecrop' cuttings by Wolfe et al. (1986).

Since blueberry plants in solution (Brown and Draper, 1980) or in medium (Wolfe et al., 1986) release $\mathrm{H}^{+}$ions that can lower the $\mathrm{pH}$ of the medium, maintenance of the $\mathrm{pH}$ levels was a concern. However, within each $\mathrm{pH}$ regime, the $\mathrm{pH}$ of the general medium and the $\mathrm{pH}$ in the immediate rhizosphere were very similar at the end of the experiment, indicating that the two buffers were effective in maintaining the initial $\mathrm{pH}$ levels $( \pm 0.1 \mathrm{pH}$ unit).

Interpopulation variation was significant, regardless of $\mathrm{pH}$ regime, for all of the traits examined (Table 3). Percent radicle emergence and plant survival varied little due to $\mathrm{pH}$ regime. A significant $(P \leq 0.05)$ difference in germination was detected between the $\mathrm{pH}$ levels, although differences were small $(78 \%$ at $\mathrm{pH}=5.0 ; 75 \%$ at $\mathrm{pH}=6.0)$. Significant variation due to $\mathrm{pH}$ regime for vitality and dry weight, but not for height, agreed with the visual observations that plants grown at higher $\mathrm{pH}$ were about the same height but had smaller leaves and were less vigorous when compared with the plants at low $\mathrm{pH}$ (Table 3 ). The population $\times \mathrm{pH}$ interaction measured the variation due to differential population responses to $\mathrm{pH}$ and should indicate the presence of higher $\mathrm{pH}$ tolerance. The population $\times \mathrm{pH}$ interaction was significant for average plant height but not for average dry weight. The populations also showed a differential response due to $\mathrm{pH}$ for the subjective vitality score.

The GCA variance components were significant for all of the traits measured (Table 3). The SCA variance components were significant for percent germination, radicle emergence, and survival, but for neither percent cotyledon emergence nor plant growth evaluation traits (Table 3). The GCA mean square was similar in magnitude to the SCA mean square for percent radicle emergence, but both were much larger (3- to 26-fold) than the SCA mean squares for all other traits. Therefore, additive genetic variance appears to be more important than nonadditive genetic variance for these traits and within this germplasm.

The variance components due to maternal and reciprocal effects might be expected to be quite important in the traits involved in seed germination and initial seedling survival because the maternal parent provides the environment for seed development and maturation. However, the variance components due to maternal effects were not significant for any of the seed germination and survival traits (Table 3). Significant maternal effects for the plant growth measurements suggested that careful selection of the maternal parent may aid the development of higher $\mathrm{pH}$-tolerant blueberries.

In general, the variance components due to reciprocal effects were similar in size to the maternal effects for the survival evaluation traits (Table 3), and, likewise, they were not significant. The variation due to crossing in one direction or another appears to be largely due to choice of maternal parent for these survival traits. Although nonsignificant, this trend was not surprising, because maternal effects would be expected to have a larger role in early plant development. However, the maternal components of variance were significant and two to three times larger than the reciprocal components of variance for the plant growth traits (Table 3).

The parental GCA effects for percent germination and survival were similar at each $\mathrm{pH}$ level, which was not surprising, based on the lack of significant $\mathrm{pH}$ regime effects for these traits. The parental GCA effects for percent germination were large and negative for MN-61 and 'Bluejay', whereas 'Northblue', GR-1, and N70145 consistently produced populations that had a higher percent germination (Table 4). The GCA effects for percent survival were large and negative for MN-61 and 'Bluejay', and large and positive for GR-1. Progenies derived from MN-61 and 'Bluejay' not only had poorer germination rates, but many of the seedlings died before or soon after cotyledon emergence. However, progenies of GR-1 not only had higher germination rates than the others, but very few of the plants that germinated subsequently died. While the parental GCA effects for the seedling emergence and survival traits were not associated with species background, GCA effects for the plant growth traits, population vitality, average height, and average dry weight were (Table 4). N70127 and N70145 at low and high $\mathrm{pH}$ had large positive effects for plant height. N70145

Table 3. Analysis of variance for survival evaluation traits for blueberry populations grown under low or high $\mathrm{pH}$ regimes in vitro.

\begin{tabular}{|c|c|c|c|c|c|c|c|c|}
\hline \multirow[b]{2}{*}{ Source } & \multirow[b]{2}{*}{$\mathrm{df}$} & \multicolumn{7}{|c|}{ Mean squares } \\
\hline & & $\begin{array}{c}\text { Germination } \\
(\%)\end{array}$ & $\begin{array}{c}\text { Radicle } \\
\text { emergence } \\
(\%)\end{array}$ & $\begin{array}{c}\text { Cotyledon } \\
\text { emergence } \\
(\%)\end{array}$ & $\begin{array}{c}\text { Survival } \\
(\%)\end{array}$ & $\begin{array}{c}\text { Plant } \\
\text { vitality }\end{array}$ & $\begin{array}{c}\text { Plant } \\
\text { ht }\end{array}$ & $\begin{array}{l}\text { Plant } \\
\text { dry wt }\end{array}$ \\
\hline Population & 62 & $8.77^{* *}$ & $17.35^{* *}$ & $25.85^{* *}$ & $7.66^{* *}$ & $8.98^{* *}$ & $364.33^{* *}$ & $0.0014^{* *}$ \\
\hline GCA & 7 & $21.03^{* *}$ & $24.25^{* *}$ & $73.85^{* *}$ & $15.77^{* *}$ & $15.19^{* *}$ & $1916.11^{* *}$ & $0.0043^{* *}$ \\
\hline SCA & 20 & $4.25^{*}$ & $21.35^{* *}$ & 18.00 & $5.62^{* *}$ & 2.25 & 73.73 & 0.0005 \\
\hline Reciprocal & 28 & 3.12 & 6.00 & 15.80 & 2.50 & $4.34^{*}$ & $162.81^{*}$ & $0.0013^{* *}$ \\
\hline Maternal & 7 & 2.70 & 5.95 & 22.25 & 2.25 & $9.28^{*}$ & $450.68 * *$ & $0.0039 * *$ \\
\hline $\mathrm{pH}$ regime & 1 & $6.20^{*}$ & 3.15 & $141.10^{* *}$ & 0.15 & $26.27^{* *}$ & 96.94 & $0.0039^{* *}$ \\
\hline pH reg. $\times$ pop. & 62 & 1.30 & $13.35 * *$ & 19.40 & 2.13 & $2.61^{* *}$ & $112.76^{*}$ & 0.0006 \\
\hline
\end{tabular}

${ }^{2}$ Vitality measured on 1-9 scale; 1 = chlorotic and/or weak, $9=$ green, healthy, and vigorous.

***F value $>1(P \leq 0.05$ and 0.01 , respectively). 
Table 4. General combining ability effects for Vaccinium parents for survival evaluation and plant growth traits under each $\mathrm{pH}$ regime (low $=\mathrm{pH} \mathrm{5.0,} \mathrm{high}=\mathrm{pH} 6.0$ ).

\begin{tabular}{|c|c|c|c|c|c|c|c|c|c|c|}
\hline \multirow[b]{2}{*}{ Parents } & \multicolumn{2}{|c|}{$\begin{array}{c}\text { Germination } \\
(\%)\end{array}$} & \multicolumn{2}{|c|}{$\begin{array}{c}\text { Survival } \\
(\%)\end{array}$} & \multicolumn{2}{|c|}{$\begin{array}{c}\text { Plant } \\
\text { vitality }\end{array}$} & \multicolumn{2}{|c|}{$\begin{array}{c}\text { Plant } \\
\text { ht }\end{array}$} & \multicolumn{2}{|c|}{$\begin{array}{l}\text { Plant } \\
\text { dry wt }\end{array}$} \\
\hline & $\begin{array}{c}\text { Low } \\
\mathrm{pH}\end{array}$ & $\begin{array}{c}\text { High } \\
\mathrm{pH}\end{array}$ & $\begin{array}{c}\text { Low } \\
\mathrm{pH}\end{array}$ & $\begin{array}{l}\text { High } \\
\mathrm{pH}\end{array}$ & $\begin{array}{l}\text { Low } \\
\text { pH }\end{array}$ & $\begin{array}{l}\text { High } \\
\mathrm{pH}\end{array}$ & $\begin{array}{c}\text { Low } \\
\mathrm{pH}\end{array}$ & $\begin{array}{c}\text { High } \\
\mathrm{pH}\end{array}$ & $\begin{array}{l}\text { Low } \\
\mathrm{pH}\end{array}$ & $\begin{array}{c}\text { High } \\
\mathrm{pH}\end{array}$ \\
\hline N70127 & -1.95 & 0.27 & -0.70 & 3.43 & 1.17 & 0.57 & 11.90 & 6.49 & 0.60 & 0.24 \\
\hline N70145 & 3.04 & 6.05 & 1.01 & & 0.95 & 0.32 & 6.70 & 6. & 0.15 & -0.05 \\
\hline GR-1 & 5.49 & 6.10 & 4.35 & 3.80 & 0.20 & 0.20 & -0.41 & 2.00 & 0.07 & 0.27 \\
\hline MN-61 & -9.77 & -9.42 & -8.36 & -12.50 & -0.64 & -0.87 & -5.66 & -2.47 & -0.18 & -0.26 \\
\hline Northblue & 2.27 & 7.77 & 3.35 & 4.06 & 0.04 & 0.42 & -2.44 & -0.23 & -0.03 & 0.17 \\
\hline B-16 & -1.02 & -1.92 & 4.76 & 1.79 & -1.05 & -0.77 & -7.85 & -7.76 & -0.51 & -0.39 \\
\hline Spartan & 5.40 & 1.83 & -2.11 & 2. & -0.77 & 0.14 & -2.53 & -0.49 & -0.16 & -0.08 \\
\hline Bluejay & -3.46 & -10.68 & -2.30 & -6.2 & 0.10 & -0.01 & 0.28 & -4.12 & 0.06 & 0.11 \\
\hline$S E^{z}$ & 2.65 & 2.57 & 2.97 & 2.91 & 0.28 & 0.27 & 1.87 & 1.48 & 0.09 & 0.12 \\
\hline
\end{tabular}

${ }^{\mathrm{z}}$ Mean standard error of parental effects.

at low $\mathrm{pH}$ and $\mathrm{N} 70127$ at high and low $\mathrm{pH}$ had positive effects for vitality. GR-1 at high $\mathrm{pH}$ and $\mathrm{N} 70127$ at low and high $\mathrm{pH}$ had large and positive effects for dry weight. The parents with $V$. angustifolium or species hybrid ancestry, except MN-61, contributed to more vigorous populations with higher dry weights (Tables 1 and 4). Those parents within this germplasm with $100 \% \mathrm{~V}$. angustifolium ancestry strongly contributed to taller plant height, regardless of $\mathrm{pH}$ level. The progenies of species hybrid derivative or $V$. corymbosum parents tended to be shorter than the rest, regardless of $\mathrm{pH}$ level. 'Bluejay', which was largely neutral for dry weight, height, and vitality GCA effects at both $\mathrm{pH}$ levels, had a very high negative effect for plant height at high pH. B-16 (V. corymbosum) and MN-61 (species-hybrid derivative) had large and negative GCA effects for vitality, height, and dry weight at both $\mathrm{pH}$ levels.

The maternal effects were largely nonsignificant (less than $2 \times \mathrm{SE}$ ), with a few exceptions (data not shown). The populations with N70145 as the maternal parent had high incidence of seed germination. However, this effect did not contribute to a higher maternal percent survival effect. B-16 had a significant and negative maternal effect for plant vitality (-6.26), height $(-48.62 \mathrm{~mm})$, and dry weight $(-3.01 \mathrm{mg})$. The combination of poor GCA effects and maternal effects suggested that B-16 would be a poor choice as a parent to enhance high $\mathrm{pH}$ tolerance. 'Northblue' and 'Bluejay' both had significant and positive maternal effects for plant vitality (3.81 and 5.25, respectively), height (23.3 and $36.6 \mathrm{~mm}$, respectively), and dry weight ( 2.22 and $3.93 \mathrm{~g}$, respectively). Within the restrictions of this study, these parents could be considered good maternal parents, although their overall GCA effect did not suggest that they are outstanding parents for transmitting higher $\mathrm{pH}$ tolerance.

Phenotypic correlation coefficients between height and dry weight were positive and high over both regimes and within the low $\mathrm{pH}$ regime, and positive but lower within the higher $\mathrm{pH}$ regime (Table 5). The vitality scores were consistently more positively correlated with plant height than dry weight, suggesting that when these cultures are subjectively evaluated, height is given more value than true vitality. Although height was more highly correlated than vitality scores with dry weight at low $\mathrm{pH}$, at high $\mathrm{pH}$ they were equal.

In general, the progenies with greater percentage lowbush ancestry were taller, had greater dry weight, and higher vitality scores than those with a larger percentage of highbush ancestry (Table 5). This trend was most noticeable for plant height in
Table 5. Correlation coefficients among plant vitality, height, and dry weight (family means over $\mathrm{pH}$ regimes and within each $\mathrm{pH}$ regime)..,$y$

\begin{tabular}{lccl}
\hline \hline $\begin{array}{l}\text { Plant } \\
\text { character }\end{array}$ & Ht & $\begin{array}{c}\text { Dry } \\
\text { wt }\end{array}$ & $\begin{array}{c}\text { Lowbush } \\
\text { ancestry } \\
(\%)\end{array}$ \\
\hline Vitality-overall & 0.73 & 0.63 & 0.39 \\
pH 5.0 & 0.79 & 0.65 & 0.51 \\
pH 6.0 & 0.67 & 0.58 & $0.27(0.03)$ \\
Ht-overall & & 0.73 & 0.54 \\
pH 5.0 & & 0.85 & 0.53 \\
pH 6.0 & & 0.59 & 0.56 \\
Dry wt-overall & & & 0.26 \\
pH 5.0 & & & 0.37 \\
pH 6.0 & & & $0.15^{\mathrm{Ns}}$ \\
\hline
\end{tabular}

zThe three correlations are for either over $\mathrm{pH}$ regimes or within the low or high $\mathrm{pH}$ regime.

$\mathrm{y}_{r} \neq 0(P \leq 0.01 ; \mathrm{df}=128$ overall and 64 within each regime $)$, unless otherwise indicated.

NSNonsignificant.

general and at low $\mathrm{pH}$ for vitality and dry weight. Plant height was positively correlated with percent lowbush ancestry at each $\mathrm{pH}$ level. The confines of this in vitro system did not allow a determination of when the largely highbush progenies would overtake the largely lowbush progenies as measured by height.

Media $\mathrm{pH}$ affected plant growth despite the availability of $\mathrm{NH}_{4}-\mathrm{N}$ and $\mathrm{NO}_{3}-\mathrm{N}$ forms and the increased availability of $\mathrm{Fe}$ with EDTA chelate. Some clarification of this statement is necessary, however. Although concentrations of Fe and other nutrients were initially the same, varying $\mathrm{pH}$ levels can affect their activity in solution (agar). A modified speciation model (GEOCHEM; Parker et al., 1987) was used to calculate activity of $\mathrm{Fe}^{3+}$ in the nutrient solutions adjusted to a $\mathrm{pH}$ of 5 and 6 . The results indicated that $\mathrm{Fe}^{3+}$ activity was 66 times greater at $\mathrm{pH}$ 5 compared to $\mathrm{pH}$ 6. To overcome this problem, future experiments should include buffering the Fe with excess chelate so that $\mathrm{pH}$ and $\mathrm{Fe}$ effects are not confounded (Chancy et al., 1989).

Little variation was observed for tolerance of higher $\mathrm{pH}$ as measured by plant dry weight within the germplasm examined in this study. However, the parental GCA effects suggested that the progenies of some parents performed better than others at high $\mathrm{pH}$ levels. There are at least two possible reasons GCA effects suggested higher $\mathrm{pH}$ tolerance even though the population $\times \mathrm{pH}$ regime interaction was not significant for dry weight: 
1) populations that were the most vigorous at high $\mathrm{pH}$ also were better at low $\mathrm{pH}$, or 2) the interaction was masked by the poorer overall performance of the populations derived from B-16 and $\mathrm{MN}-61$. The first alternative may not be appropriate because the progenies of GR-1 grew better than many others at high $\mathrm{pH}$ but were similar to other populations at low $\mathrm{pH}$. Progenies of GR-1 were also considered more tolerant of high $\mathrm{pH}$ in a field study where 2-year-old plants were evaluated (Finn, 1989).

In general, the populations derived from parents that had a large proportion of $V$. angustifolium ancestry, especially those of N70127, performed better than others at high $\mathrm{pH}$ and overall, but the progenies of MN-61 (50\% lowbush) were significant exceptions. Although others have proposed that $V$. angustifolium could be a general source of genes for tolerance to high $\mathrm{pH}$ (Galletta, 1975; Korcak, 1986a, 1986b; Korcak et al., 1982), our data suggest that individual $V$. angustifolium genotypes differed to the extent that some pass increased tolerance to high $\mathrm{pH}$ to progeny and others do not. Therefore, careful selection of parental material is critical.

In vitro screening in concert with a traditional breeding program should be effective in improving blueberry tolerance to high $\mathrm{pH}$ in a manner similar to the Fe-efficiency screening procedure of Brown and Draper (1980). Based on the importance of GCA variance within this germplasm, a breeding system using recurrent, phenotypic (mass) selection to obtain genotypes with greater $\mathrm{pH}$ tolerance in vitro should be successful.

\section{Literature Cited}

Bailey, J.S. 1941. Effect of lime application on the growth of cultivated blueberry plants. Proc. Amer. Soc. Hort. Sci. 38:465-467.

Ballinger, W.E. 1966. Soil management, nutrition and fertilizer practices, p. 132-171. In: P. Eck and N.F. Childers (eds.). Blueberry culture. Rutgers Univ. Press, New Brunswick, N.J.

Bradley, G.A. and D. Smittle. 1965. Media pH, extractable Fe, Al, Mn in relation to growth of Ericaceous plants. Proc. Amer. Soc. Hort. Sci. 87:486-493.

Brown, J.C. and A.D. Draper. 1980. Differential response of blueberry (Vaccinium) progenies to $\mathrm{pH}$ and subsequent use of iron. J. Amer. Soc. Hort. Sci. 105:20-24.

Cain, J.C. 1952. A comparison of ammonium and nitrate nitrogen for blueberries. Proc. Amer. Soc. Hort. Sci. 59:161-166.

Cain, J.C. and R.W. Honey. 1955. A comparison of chlorotic and green blueberry tissue with respect to free amino acid and basic cation content. Proc. Amer. Soc. Hort. Sci. 65:49-53.

Chandler, C.K., A.D. Draper, G.J. Galletta, and J.C. Bouwkamp. 1985. Combining ability of blueberry interspecific hybrids for growth on upland soil. HortScience 20:257-258.

Chandler, C.K. and A.D. Draper. 1986. Effect of zeatin and 2iP on shoot proliferation of three highbush blueberry clones in vitro. HortScinece 21:1065-1066.

Chancy, R.L., P.F. Bell, and B.A. Coulombe. 1989. Screening strategies for improved nutrient uptake and use by plants. HortScience. 24:565572.

Coville, F.V. 1910. Experiments in blueberry culture. U.S. Dept. Agr. Bul. 193.

Finn, C.E. 1989. Germplasm sources and screening methods to develop higher $\mathrm{pH}$ tolerance. in Vaccinium. PhD Diss., Univ. of Minnesota, St. Paul. (Diss. Abstr. 50-09B).

Finn, C., J. Luby, C. Rosen, and P. Ascher. 1987. Screening blueberry genotypes for higher $\mathrm{pH}$ tolerance. HortScience 22:97 (Abstr.)

Frett, J.J. and J.M. Smagula. 1983. In vitro production of lowbush blueberry. Can. J. Plant Sci. 63:467-472.

Galletta, G.J. 1975. Blueberries and cranberries; p. 154-196. In: J. Janick and J.N. Moore (eds.). Advances in fruit breeding. Purdue Univ. Press. West Lafayette, Ind.

Griffing, B. 1956. Concept of general and specific combining ability in relation to diallel crossing systems. Austral. J. Biol. Sci. 9:463-493.

Hall, I.V. 1976. Callus formation in stem internode sections of lowbush blueberry ( $V$. angustifolium Ait.) cultured on media containing plant growth regulators. Hort. Res. 61:29-35.

Hall, I.V., L.E. Aalders, and L. Townsend. 1964. The effects of soil $\mathrm{pH}$ on the mineral composition and growth of the lowbush blueberry. Can. J. Plant Sci. 44:433-438.

Harmer, P. 1944. The effect of varying the reaction of organic soil on the growth and production of the domesticated blueberry. Soil Sci. Soc. Proc. 9:133-141.

Havill, D.C., J.A. Lee, and G.R. Stewart. 1974. Nitrate utilization by species from acidic and calcareous soils. New Phytol. 73:1221-1231.

Holmes, R.S. 1960. Effect of phosphorus and $\mathrm{pH}$ on iron chlorosis in blueberry in water culture. Soil Sci. 90:374-399.

Hurwitz, C.D. and G.N. Agrios. 1984. Isolation and culture of protoplasts form apple callus and cell suspension culture. J. Amer. Soc. Hort. Sci. 109:348-350.

Ingestad, T. 1973. Mineral nutrient requirements of Vaccinium vitis-idaea and V. myrtillus. Physiol. Plant. 29:239-246.

Johnston, S. 1948. The behavior of highbush and lowbush blueberry selections arid their hybrids growing on various soils located at different levels. Mich. Agr. Expt. Sta. Tech. Bul. 205.

Korcak, R.F. 1986a. Adaptation of blueberry species to various soil types. I. Growth and initial fruiting. J. Amer. Soc. Hort. Sci. 111:816-821.

Korcak, R.F. 1986b. Adaptation of blueberry species to various soil types: II. Leaf and soil analysis. J. Amer. Soc. Hort. Sci. 111:822-828.

Korcak, R.F. 1989. Variation in nutrient requirements of blueberries and other calcifuges. HortScience 24:573-578.

Korcak, R.F., G.J. Galletta, and A.D. Draper. 1982. Response of blueberry seedlings to a range of soil types. J. Amer. Soc. Hort. Sci. 107:11531160.

Kouider, M., R.M. Skirvin, and S. Korban. 1984. Callus formation from Malus $\times$ domestica cv. 'Jonathan' protoplasts. Plant Cell. Rpt. 3:142145.

Kramer, A. and A.L. Schrader. 1942. Effect of nutrients, media and growth substances on the growth of the Cabot variety of Vaccinium corymbosum. J. Agr. Res. 65:313-328.

Lyrene, P.M. 1980. Micropropagation of rabbiteye blueberries. HortScience 15:80-81.

McPheeters, K. and R.M. Skirvin. 1980. Chimeral manipulation of blackberry. HortScience 15:83. (Abstr.)

Navarro, L., J.M. Oritz, and J. Juarez. 1985. Aberrant citrus plants obtained by somatic embryogenesis of nucelli cultured in vitro. HortScience 20:214-215.

Nickerson, N.L. 1978. In vitro shoot formation in lowbush blueberry seedling explants. HortScience 13:698.

Parker, D.R., L.W. Zelanzy, and T.B. Kinraide. 1987. Improvements to the program GEOCHEM. Soil Sci. Soc. Amer. J. 51:488-491.

Rorison, I.H. 1986. The response of plants to acid soils. Experiential 42:357362.

Townsend, L.R. 1966. Effect of nitrate and ammonium nitrogen on the growth of lowbush blueberry. Can. J. Plant Sci. 46:209-210.

Townsend, L.R. 1967. Effect of ammonium nitrogen and nitrate nitrogen separately and in combination on the growth of the highbush blueberry. Can. J. Plant Sci. 46:555-562.

Townsend, L.R. 1969. Influence of form of nitrogen and $\mathrm{pH}$ on growth and nutrient levels in the leaves and roots of lowbush blueberry. Can. J. Plant Sci. 49:333-338.

Twyman, E.S. 1946. The iron-manganese balance and its effect on the growth and development of plants. New Phytol. 45:18-24.

Twyman, E.S. 1950. The iron and manganese requirements of plants. New Phytol. 50:210-225.

Wolfe, D.E., P. Eck, and C.K. Chin. 1983. Evaluation of seven media for micropropagation of highbush blueberry. HortScience 18:703-705.

Wolfe, D., C.K. Chin, and P. Eck. 1986. Relationship of the $\mathrm{pH}$ of medium to growth of 'Bluecrop' highbush blueberry in vitro. HortScience 21:296-298

Young, M.J. and J.S. Cameron. 1985. Influence of growth regulators and nitrogen form on micropropagation of rabbiteye blueberries. Fruit Var. J. 39:16-18

Zimmerman, R.H. and O.C. Broome. 1980. Blueberry micropropagation. Proc. Conf. Nursery Production of Fruit Plants Through Tissue CultureApplications and Feasibility. U.S. Dept. Agr., Sci., and Educ. Adm. Agr. Res. Results, ARR-NE-11. p. 44-47. 